\title{
Contrasting effects of invasive insects and fire on ecosystem water use efficiency
}

\author{
K. L. Clark ${ }^{1}$, N. S. Skowronski ${ }^{2}$, M. R. Gallagher ${ }^{1}$, H. Renninger ${ }^{3}$, and K. V. R. Schäfer ${ }^{3}$ \\ ${ }^{1}$ Silas Little Experimental Forest, USDA Forest Service, 501 Four Mile Road, New Lisbon, NJ 08064, USA \\ ${ }^{2}$ Northern Research Station, USDA Forest Service, 180 Canfield St., Morgantown, WV 26505, USA \\ ${ }^{3}$ Rutgers University, Dept. of Biological Sciences, 195 University Ave., Newark, NJ 07102, USA \\ Correspondence to: K. L. Clark (kennethclark@fs.fed.us)
}

Received: 6 May 2014 - Published in Biogeosciences Discuss.: 20 June 2014

Revised: 26 October 2014 - Accepted: 28 October 2014 - Published: 1 December 2014

\begin{abstract}
We used eddy covariance and meteorological measurements to estimate net ecosystem exchange of $\mathrm{CO}_{2}$ (NEE), gross ecosystem production (GEP), evapotranspira-

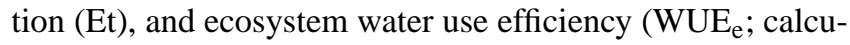
lated as GEP/Et during dry canopy conditions) in three upland forests in the New Jersey Pinelands, USA, that were defoliated by gypsy moth (Lymantria dispar L.) or burned using prescribed fire. Before disturbance, half-hourly daytime NEE during full sunlight conditions, daily GEP, and daily WUE $_{\mathrm{e}}$ during the summer months were greater at the oakdominated stand compared to the mixed or pine-dominated stands. Both defoliation by gypsy moth and prescribed burning reduced stand leaf area and nitrogen mass in foliage. During complete defoliation in 2007 at the oak stand, NEE during full sunlight conditions and daily GEP during the summer averaged only 14 and $35 \%$ of pre-disturbance values. Midday NEE and daily GEP then averaged 58 and $85 \%$, and 71 and $78 \%$ of pre-defoliation values 1 and 2 years following complete defoliation, respectively. Prescribed fires conducted in the dormant season at the mixed and pinedominated stands reduced NEE during full sunlight conditions and daily GEP during the following summer to 57 and $68 \%$, and 79 and $82 \%$ of pre-disturbance values, respectively. Daily GEP during the summer was a strong function of $\mathrm{N}$ mass in foliage at the oak and mixed stands, but a weaker function of $\mathrm{N}$ in foliage at the pine-dominated stand. Ecosystem $\mathrm{WUE}_{\mathrm{e}}$ during the summer at the oak and mixed stands during defoliation by gypsy moth averaged 1.6 and $1.1 \mathrm{~g} \mathrm{C} \mathrm{kg} \mathrm{H}_{2} \mathrm{O}^{-1}$, representing 60 and $46 \%$ of predisturbance values. In contrast, prescribed fires at the mixed and pine-dominated stands had little effect on $\mathrm{WUE}_{\mathrm{e}}$. Two
\end{abstract}

years following complete defoliation by gypsy moth, $\mathrm{WUE}_{\mathrm{e}}$ during the summer averaged $2.1 \mathrm{~g} \mathrm{C} \mathrm{kg} \mathrm{H}_{2} \mathrm{O}^{-1}, 80 \%$ of predisturbance values. $\mathrm{WUE}_{\mathrm{e}}$ was correlated with canopy $\mathrm{N}$ content only at the oak-dominated stand. Overall, our results indicate that $\mathrm{WUE}_{\mathrm{e}}$ during and following non-stand replacing disturbance is dependent on both the type and time since disturbance.

\section{Introduction}

Understanding the effects of disturbance and recovery on stand productivity and evapotranspiration (Et) is essential for accurate estimates of carbon storage and water yield in forest ecosystems. Successful forest management decisions in the future will need to consider the impacts of invasive insects, fire, windstorms and other perturbations when evaluating trade-offs between maximizing carbon sequestration to mitigate the effects of climate change, while simultaneously providing water for agriculture and municipal needs. A useful metric for characterizing the interactions between $\mathrm{CO}_{2}$ assimilation and water use by plants is water use efficiency (WUE), defined as the amount of $\mathrm{C}$ assimilated per unit of water transpired (Farquhar and Sharkey, 1982). At the ecosystem scale, a related metric is ecosystem water use efficiency $\left(W_{U} E_{e}\right)$, which can be calculated from eddy covariance data as gross ecosystem productivity (GEP) per unit Et during dry canopy conditions (Law et al., 2002; Kuglitsch et al., 2008; Jassal et al., 2009).

GEP and Et are reduced immediately following major disturbances in forests, and remain below pre-disturbance levels 
for some period of time during recovery (Thornton et al., 2002; Clark et al., 2004; Mkhabela et al., 2009; Amiro et al., 2010; Dore et al., 2010; Hicke et al., 2012). Recovery of GEP following disturbance is strongly linked to increases in leaf area and foliar nutrient capital, as well as climatic variation (Amiro et al., 2010; Thornton et al., 2002). In comparison, Et rates typically recover more rapidly following disturbance, in part because of the increased importance of evaporation from litter and soil in disturbed stands (Gholz and Clark, 2002; Mkabela et al., 2009; Biederman et al., 2014). As a consequence, $W_{U} E_{e}$ may require a number of years to recover to pre-disturbance values following severe disturbances such as clear-cut harvesting or severe wildfires (Clark et al., 2004; Makhebela et al., 2009; Dore et al., 2010). Ecosystem respiration $\left(R_{\text {eco }}\right)$ has been shown to be relatively invariant through time following a wide range of disturbances and intensities (Amiro et al., 2010; Moore et al., 2013; Reed et al., 2014). Thus, large variations in net $\mathrm{CO}_{2}$ exchange (NEE) can occur during and immediately following disturbance during the recovery process (Amiro et al., 2010). Overall, an important result of these research efforts is that GEP and NEE are typically more sensitive to severe disturbances than Et during the recovery phase in forest ecosystems.

Fewer studies have estimated changes in GEP and Et following non-stand replacing disturbances such as insect defoliation or low intensity fires, limiting our understanding of patterns of forest productivity and water use during recovery. These events can reduce leaf area, alter forest floor mass, and affect the distribution of nutrients, but typically do not significantly reduce overall stand biomass (Lovett et al., 2006; Clark et al., 2010, 2012, 2014). An important question becomes how closely are the recovery of GEP and $\mathrm{WUE}_{\mathrm{e}}$ related to leaf area and canopy nutrient status following nonstand replacing disturbances?

In this study, we quantified the effects of insect defoliation and prescribed fire on NEE, $R_{\text {eco }}$, GEP and Et in three upland forests in the Pinelands National Reserve in southern New Jersey, USA, from 2005 to 2009. We used biometric measurements to quantify leaf area index (LAI), biomass accumulation, and canopy and understory $\mathrm{N}$ pools in foliage. Eddy covariance and meteorological measurements were used to estimate NEE, $R_{\mathrm{eco}}$, GEP and Et at half-hourly, daily and annual time steps. We then used flux data collected during dry canopy conditions in the summer to calculate $\mathrm{WUE}_{\mathrm{e}}$ for pre- and post-disturbance periods. Finally, we evaluated factors contributing to temporal variability in GEP, Et and $W_{U}$ in each stand as they recovered from disturbance. We asked (1) how do GEP and WUE $\mathrm{e}_{\mathrm{e}}$ vary among oak and pine-dominated stands growing in the same climate and soil type before disturbance, and (2) how are LAI and canopy $\mathrm{N}$ content linked to GEP and $\mathrm{WUE}_{\mathrm{e}}$ during recovery from non-stand replacing disturbances (gypsy moth defoliation and prescribed fire) in these stands?

\section{Methods}

\subsection{Research sites}

Research sites were located in Burlington and Ocean counties in the Pinelands National Reserve (PNR) in southern New Jersey, USA. The PNR comprises 445000 ha of upland and wetland forest, and is the largest continuous forested landscape on the Northeastern Coastal Plain. The climate is cool temperate, with mean monthly temperatures averaging 0.3 and $24.3^{\circ} \mathrm{C}$ in January and July, respectively (1980-2009; State Climatologist of New Jersey). Average annual precipitation is $1159 \pm 156 \mathrm{~mm}$ (mean \pm 1 standard deviation; SD), approximately half of which is estimated to return to the atmosphere as evapotranspiration (Et; Rhodehamel, 1979; Dow, 2007; Clark et al., 2012). Soils of the Kirkwood and Cohansey formations are sandy, coarsegrained, and have extremely low nutrient status and cation exchange capacity (Tedrow, 1986). Although commercial forestry is limited in the PNR, upland forests are characterized by frequent disturbances such as wildfires and prescribed burns (Little and Moore, 1949; Forman and Boerner, 1981), wind events (Matlack et al., 1993), and insect defoliation events (Clark et al., 2010), all of which can significantly reduce LAI and affect the distribution of nutrients within stands. Upland forests comprise $62 \%$ of the forested area in the PNR, and are composed of three major communities; (1) oak-dominated stands, consisting of chestnut oak (Quercus prinus L.), black oak ( $Q$. velutina Lam.), white oak $(Q$. alba L.), scarlet oak (Q. coccinea Münchh.), and scattered pitch pine (Pinus rigida Mill.) and shortleaf pine ( $P$. echinata Mill.), (2) mixed pine-oak stands, with pitch pine and mixed oaks in the overstory, and (3) pitch pine-dominated stands, with few overstory oaks but abundant scrub oaks ( $Q$. marlandica Münchh. Q. ilicifolia Wangenh.) in the understory (McCormick and Jones, 1973; Lathrop and Kaplan, 2004; Skowronski et al., 2007). Ericaceous shrubs occur in the understory in all stands, primarily huckleberry (Gaylussacia baccata (Wangenh.) K. Koch) and blueberry (Vaccinium spp.). Sedges, mosses and lichens also occur in the understory.

\subsection{Biometric measurements}

Three intermediate age stands were selected for intensive study; an oak-dominated stand at the Silas Little Experimental Forest in Brendan Byrne State Forest, a mixed pine-oak stand on the Department of Defense McGuire-Dix-Lakehurst Base, and a pine-dominated stand in the New Jersey Division of Fish and Wildlife's Greenwood Wildlife Management Area (Table 1; Skowronski et al., 2007; Clark et al., 2010, 2012), referred to below as the oak, mixed, and pine stands, respectively. Stands were located $17.2 \pm 2.8 \mathrm{~km}$ apart (mean $\pm 1 \mathrm{SD}$ ) in an approximate triangle formation. Stands were selected to represent the dominant age class (75-95 years) 
Table 1. Forest structure at the oak, mixed, and pine stands at the beginning of the study in 2005 . Overstory data are from five $201 \mathrm{~m}^{2}$ plots measured in 2005, understory biomass is from 10 to $201.0 \mathrm{~m}^{2}$ clip plots, and forest floor mass (Oi layer) is from ten $1.0 \mathrm{~m}^{2}$ plots in the vicinity of the tower at each site. Values are means \pm 1 standard error.

\begin{tabular}{lrrr}
\hline Variable & Oak & Mixed & Pine \\
\hline Stem density $\left(\right.$ stems ha $\left.^{-1}\right)$ & & & \\
Pine & $90 \pm 19$ & $269 \pm 162$ & $1035 \pm 87$ \\
Oak & $1233 \pm 293$ & $676 \pm 114$ & $418 \pm 145$ \\
Total & $1323 \pm 300$ & $945 \pm 123$ & $1452 \pm 158$ \\
\hline Basal area $\left(\mathrm{m}^{2} \mathrm{ha}^{-1}\right)$ & & & \\
Pine & $4.4 \pm 2.4$ & $5.6 \pm 1.8$ & $14.3 \pm 2.1$ \\
Oak & $11.5 \pm 1.4$ & $6.3 \pm 4.2$ & $0.3 \pm 0.1$ \\
Total & $15.9 \pm 2.5$ & $11.8 \pm 3.0$ & $14.7 \pm 2.1$ \\
\hline Overstory biomass $\left(\mathrm{g} \mathrm{m}^{-2}\right)$ & & & \\
Pine & $2134 \pm 1179$ & $1957 \pm 612$ & $4956 \pm 1018$ \\
Oak & $6360 \pm 736$ & $3227 \pm 2294$ & $54 \pm 21$ \\
Total & $8494 \pm 1220$ & $5184 \pm 1859$ & $5010 \pm 1023$ \\
\hline Understory biomass $\left(\mathrm{g} \mathrm{m}^{-2}\right)$ & & & \\
Oaks & $20 \pm 15$ & $217 \pm 71$ & $70 \pm 23$ \\
Ericaceae & $168 \pm 38$ & $112 \pm 32$ & $322 \pm 27$ \\
Total & $189 \pm 35$ & $529 \pm 150$ & $397 \pm 44$ \\
\hline Forest floor mass $\left(\mathrm{g} \mathrm{m}^{-2}\right)$ & & & \\
Fine litter & $845 \pm 45$ & $842 \pm 71$ & $1131 \pm 35$ \\
Wood & $223 \pm 47$ & $319 \pm 63$ & $447 \pm 110$ \\
Total & $1068 \pm 75$ & $1160 \pm 115$ & $1578 \pm 119$ \\
\hline
\end{tabular}

of the three major upland forest types in the PNR, based on USFS Forest Inventory and Analysis data (http://www.fia. fs.fed.us/). We randomly located five circular $201 \mathrm{~m}^{2}$ forest census plots within $100 \mathrm{~m}$ of the eddy covariance tower in each stand (Table 1). Annual measurements of tree diameter at breast height $(1.37 \mathrm{~m})$ and tree height were conducted for all stems $\geq 5.0 \mathrm{~cm} \mathrm{dbh}$ in each plot, and tree biomass was estimated from published allometric relationships (Whittaker and Woodwell, 1968; Skowronski et al., 2007). Fine litterfall was collected approx. monthly when present from two $0.42 \mathrm{~m}^{2}$ wire mesh traps adjacent to each tree census plot, for a total of $n=10$ traps in each stand. Litterfall was separated into needles, leaves, stems, reproductive material and frass from trees and shrubs, dried at $70{ }^{\circ} \mathrm{C}$ and then weighed. Ten to twenty clip plots $\left(1.0 \mathrm{~m}^{2}\right)$ located randomly within $200 \mathrm{~m}$ of each tower were harvested during the time of peak biomass in mid-summer every year to estimate the aboveground biomass of understory shrubs and oaks $<2 \mathrm{~m}$ tall. Understory vegetation samples were separated into leaves, needles, stems and reproductive material, dried at $70^{\circ} \mathrm{C}$ and then weighed. Specific leaf area (SLA; $\mathrm{m}^{2} \mathrm{~g}$ dry weight ${ }^{-1}$ ) for each major species was measured with a leaf area meter (LI-3000a, LI-COR Inc., Lincoln, Nebraska, USA) and a conveyer belt (LI-3050c, LI-COR Inc.) using fresh leaf, needle or litterfall samples, which were then dried at $70^{\circ} \mathrm{C}$ and weighed. Maximum annual canopy leaf area index (LAI; $\mathrm{m}^{2} \mathrm{~m}^{-2}$ ground area) was estimated for each species by multiplying litterfall mass by the appropriate SLA value and then summing results for all species. Projected leaf area of pine needle fascicles was multiplied by $\pi$ to calculate an all-sided LAI (e.g., Gholz et al., 1994). Understory LAI was estimated by multiplying foliage mass obtained from each clip plot by the corresponding SLA values.

Canopy and understory foliage were sampled for $\mathrm{N}$ content at the time of peak leaf area during the summer at each stand throughout the study. The oak stand was completely defoliated by gypsy moth prior to maximum leaf area during the growing season in 2007 , therefore foliage was sampled in mid-July following the second leaf flush. Oven-dried samples of live foliage were ground using a Wiley mill (Thomas Scientific, Swedesboro, NJ, USA) and digested along with appropriate standards using a modified Kjeldahl method (Allen, 1989). An Astoria 2 Analyzer (Astoria-Pacific International, Clackamas, OR, USA) was used to measure the ammonium concentration of each sample, and results were converted to $\mathrm{N}$ concentration in foliage. Nitrogen mass $\left(\mathrm{g} \mathrm{N} \mathrm{m}^{-2}\right.$ ground area) in canopy and understory foliage was calculated for dominant species by multiplying species-specific $\mathrm{N}$ concentrations by corresponding estimates of foliar biomass (e.g., Hoover, 2008). 
Table 2. Energy balance closure for the oak, mixed and pine stands for all half-hourly data collected from 2005 to 2009. Halfhourly flux data were fit to the equation $R_{\text {net }}-G$-storage terms $=\alpha$ $(H+\lambda E)+\beta$. Data were filtered for $u^{*}$ values $<0.2 \mathrm{~m}^{-2}$, precipitation, and instrument malfunction. Values are means \pm 1 Standard error, and all correlations are significant at $P<0.001$. Energy balance closure for each stand by year is in Clark et al. (2012).

\begin{tabular}{lcccc}
\hline Stand & $\alpha$ & $\beta$ & $r^{2}$ & $n$ \\
\hline Oak & $0.96 \pm 0.01$ & $14.53 \pm 0.27$ & 0.86 & 44941 \\
Mixed & $0.99 \pm 0.01$ & $8.88 \pm 0.26$ & 0.92 & 21682 \\
Pine & $0.96 \pm 0.01$ & $8.39 \pm 0.26$ & 0.90 & 44912 \\
\hline
\end{tabular}

\subsection{NEE, GEP, Et, and water use efficiency}

Net ecosystem exchange of $\mathrm{CO}_{2}$ (NEE) and latent heat flux $(\lambda E)$ were measured using eddy covariance systems mounted on towers above the canopy at each stand, and then gapfilled to estimate daily to annual NEE and Et (Falge et al., 2001; Clark et al., 2010, 2012). Ecosystem respiration $\left(R_{\text {eco }}\right)$ was calculated for each site using continuous half-hourly air (growing season) or soil (dormant season) temperature data and an exponential equation to predict the temperature dependence of respiration developed from nighttime NEE measurements. We summed NEE and $R_{\text {eco }}$ at daily and annual timescales to estimate gross ecosystem production, GEP.

$\mathrm{GEP}=\mathrm{NEE}+R_{\mathrm{eco}}$

Ecosystem water use efficiency ( $\mathrm{WUE}_{\mathrm{e}} ; \mathrm{g} \mathrm{C} \mathrm{kg} \mathrm{H}_{2} \mathrm{O}^{-1}$ ) was defined as the ratio of daily gross ecosystem productivity (GEP) to evapotranspiration (Et) during dry canopy conditions.

$\mathrm{WUE}_{\mathrm{e}}=\mathrm{GEP} / \mathrm{Et}$

Meteorological and eddy flux measurements were made from pairs of overstory (16 or $18.5 \mathrm{~m})$ and understory $(3 \mathrm{~m})$ towers in each stand. Shortwave radiation $\left(R_{\mathrm{g}}\right.$; LI-200, LI-COR, Inc.), photosynthetically active radiation (PAR; LI-190, LICOR, Inc.), net radiation ( $R_{\text {net }}$; NRLite, Kipp and Zonen, Inc., Delft, the Netherlands), air temperature and relative humidity (HMP45, Vaisala, Inc., Woburn, MA, USA), wind speed and direction (05013-5, R. M. Young Co., Traverse City, MI, USA), and precipitation (TE525, Texas Electronics, Inc., Dallas, TX, USA) were measured at the top of each overstory tower and at $2 \mathrm{~m}$ height on each understory tower. Soil heat flux was measured using three heat flux transducers (HFT-3.1, Radiation and Energy Balance Systems, Inc., Seattle, WA, USA) buried at $10 \mathrm{~cm}$ depth within $10 \mathrm{~m}$ of the towers. Soil temperature (CS-107 or CS-109, Campbell Scientific, Inc., Logan, UT, USA) was measured at $5 \mathrm{~cm}$ depth in at least three locations at each stand. Meteorological data were recorded at half-hourly intervals with automated data loggers (CR10x, CR23x and CR1000, Campbell Scientific,
Inc.). A complete description of sensor type and location appears in Clark et al. (2012).

Eddy covariance systems were composed of a 3dimensional sonic anemometer (Windmaster Pro, Gill Instruments Ltd., Lymington, UK, or RM $80001 \mathrm{~V}$, R. M. Young, Inc.), a closed-path infrared gas analyzer (LI-7000, LI-COR Inc.), a $5 \mathrm{~m}$ long, $0.4 \mathrm{~cm}$ ID teflon coated tube and an air pump (UN726-FTP, KNF-Neuberger, Trenton, NJ, USA). $10 \mathrm{~Hz}$ data were recorded on laptop computers at each stand. The sonic anemometer was mounted $4 \mathrm{~m}$ above the canopy at each stand. The inlet of the air sampling tube was located between the upper and lower sensors of the sonic anemometer, and air was drawn through the LI-7000 at a rate of approx. $8.0 \mathrm{~L} \mathrm{~min}^{-1}$ so that the mean lag time was $\leq 2.5 \mathrm{~s}$. The LI-7000's were calibrated every 2-10 days using $\mathrm{CO}_{2}$ traceable to primary standards and a sling psychrometer or a LI-610 dew point generator. Net $\mathrm{CO}_{2}, H$, and $\lambda E$ fluxes were calculated at half-hour intervals using the EdiRe program (Edinburgh, UK). Barometric pressure data (PTB 110, Vaisala, Inc.) was then used to calculate fluxes at ambient atmospheric pressure. The flux associated with the change in storage of $\mathrm{CO}_{2}$ in the air column beneath the sonic anemometer was estimated using top of tower and $2 \mathrm{~m}$ height measurements (LI-840, LI-COR Inc.) or a profile system with inlets at $0.2,2,5,10,15$, and $18.5 \mathrm{~m}$ height (oak stand only). Half-hourly NEE was then calculated as the sum of net $\mathrm{CO}_{2}$ flux $\left(f_{\mathrm{CO}_{2}}\right)$ and the storage flux for each half hour period. Data were filtered for low turbulence conditions when friction velocity $\left(u^{*} ; \mathrm{m} \mathrm{s}^{-1}\right)$ was $<0.2 \mathrm{~m} \mathrm{~s}^{-1}$ (Falge et al., 2001), when precipitation occurred, and for instrument malfunction. All meteorological and eddy flux data are available from the AmeriFlux web site (http://public.ornl.gov/ameriflux;US-slt, US-dix,US-ced).

The three extensive, relatively flat stands had near ideal fetch for above-canopy eddy covariance measurements (Skowronski et al., 2007). Minimum fetch was approximately 1260,530 , and $690 \mathrm{~m}$ at the oak, mixed, and pine stands, respectively. We evaluated energy balance closure using the relationship between the sum of $H+\lambda E$ and available energy $\left(R_{\text {net }}-G-\Delta S_{\text {air }}-\Delta S_{\text {bio }}\right)$ for all half-hourly data collected at each stand using linear regression in SigmaPlot 10 (SYSTAT Software, Inc.) (Clark et al., 2012; Table 2). To estimate NEE for daytime periods when we did not have measurements (due to low wind-speed conditions, precipitation, instrument failure, etc.), we fit a parabolic function (growing season) or a linear function (dormant season) to the relationship between PAR and NEE at bi-weekly to monthly intervals (Clark et al., 2004, 2010). For nighttime periods, we fit an exponential function to the relationship between air temperature (growing season) or soil temperature (dormant season) and NEE. Coefficients for gap filling were calculated from data collected during the appropriate time periods using SigmaPlot regression software. We used \pm 1 standard error (SE) of the value of each parameter in the parabolic function for daytime data during the summer, and in the exponential 

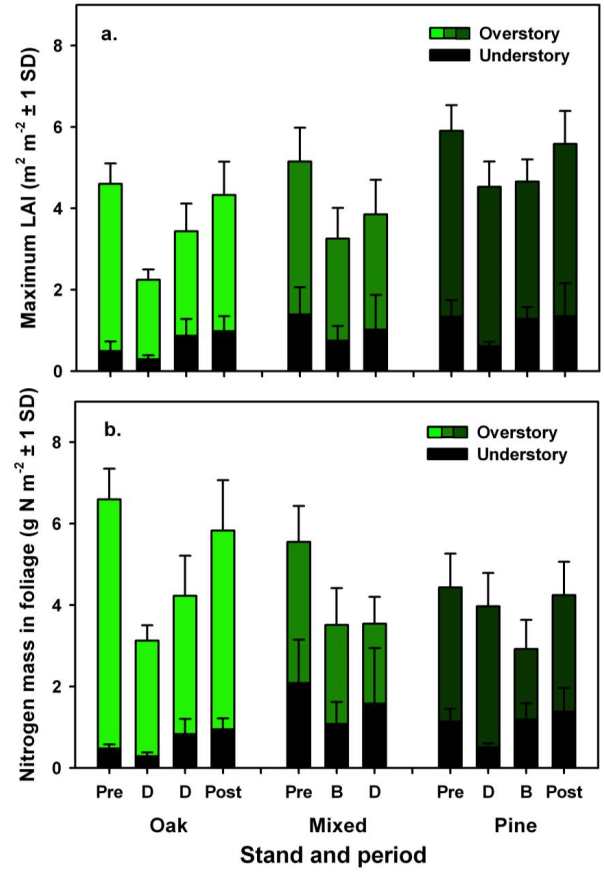

Figure 1. (a) Maximum leaf area index (LAI; $\mathrm{m}^{2} \mathrm{~m}^{-2}$ ground area \pm 1 standard deviation) and (b) maximum nitrogen content in foliage $\left(\mathrm{g} \mathrm{N} \mathrm{m}^{-2}\right.$ ground area \pm 1 standard deviation) during the summer at the oak, mixed, and pine stands from 2004 to 2009. Data are shown for understory, overstory and total LAI and $\mathrm{N}$ content. Pre = pre-disturbance, $D=$ defoliation by Gypsy moth, $B=$ burned in prescribed fire, Post $=$ post-disturbance. Pre-disturbance at the oak stand was 2004-2006, complete defoliation by gypsy moth occurred in 2007, partial defoliation by gypsy moth occurred in 2008, and post-disturbance was 2009 . Pre-disturbance at the mixed stand was 2005, a prescribed fire was conducted on 9 February 2006, and defoliation of deciduous species by gypsy moth occurred in 2007. Pre-disturbance at the pine stand was 2005-2006, defoliation of primarily understory vegetation by gypsy moth occurred in 2007, a prescribed fire was conducted on 23 March 2008, and postdisturbance was 2009.

function for all nighttime data to evaluate the sensitivity of annual NEE estimates to modeled values. To estimate $\lambda E$ for periods when we did not have measurements, we fit a linear function to the relationship between available energy and $\lambda E$ at bi-weekly (e.g., 1-14 May) to bi-monthly (e.g., 1 July-31 August ) intervals (Clark et al., 2012). We then used modeled half-hourly data to fill in periods when we did not have measured fluxes to calculate daily to annual NEE and Et for each stand.

\subsection{Statistical analyses}

We focused our analyses of NEE, Et and GEP on the summer months (1 June to 31 August), corresponding to the period when deciduous species were at their peak photosynthetic activity (Renninger et al., 2013). We evaluated patterns of $\mathrm{WUE}_{\mathrm{e}}$ during the summers before, during and af- ter each disturbance event. In order to maximize the contribution of transpiration to Et in these calculations, we used data collected when we assumed the canopy was dry, and days with recorded precipitation and the day following each rain event when precipitation $\geq 10 \mathrm{~mm}$ were excluded from further analyses. We used ANOVA analyses to test significance levels of the differences in daytime and nighttime NEE among stands before disturbance, and within stands pre- and post-disturbance. Half-hourly NEE values were not independent or normally distributed, thus we randomly sampled $n=50$ NEE values and then calculated a mean value 100 times for each period (day or night), stand (oak, mixed, pine), and year for ANOVA analyses (SYSTAT 12, SYSTAT Software, Inc.). Daily values of GEP, Et and $\mathrm{WUE}_{\mathrm{e}}$ among stands and within stands among years during the summer were compared using repeated-measures ANOVA analyses that permit correlated error structure to account for the lack of independence among variables. Comparisons among stands or years within each stand were made with Tukey's Honestly Significant Difference (HSD) tests that adjusted significance levels for multiple comparisons. We used non-linear regression analyses to determine the relationship between daily Et and GEP. Differences in the values of regressions between daily Et and GEP were detected using $T$ tests and ANCOVA analyses.

\section{Results}

\subsection{Leaf area and nitrogen content of foliage}

Maximum LAI during the summer averaged 4.8 to 6.0 at the three stands before disturbance, with overstory species accounting for 89,73 , and $77 \%$ of total LAI during the summer at the oak, mixed and pine stands, respectively (Fig. 1a). LAI during the winter averaged $0.5 \pm 0.5,0.7 \pm 0.4$ and $1.4 \pm 0.4$ at the oak, mixed and pine stands, respectively (data not shown). Nitrogen mass in foliage during the summer before disturbance was greatest at the oak stand and least at the pine stand (Fig. 1b).

At the oak stand, herbivory by gypsy moth during the early summer of 2007 reduced LAI to $<0.5$ (see Schäfer et al., 2010). Following the peak of herbivory in June, a second partial leaf-out resulted in a total LAI of only 2.3 (Fig. 1a). Nitrogen mass of canopy and understory foliage following the second leaf out was only ca. $42 \%$ of predisturbance levels (Fig. 1b). In 2008, partial defoliation reduced LAI again, although a second leaf out did not occur. Nitrogen mass in foliage was lower in 2008 compared to pre-defoliation periods, because species-weighted foliar $\mathrm{N}$ concentration of the canopy was slightly lower $(1.7 \% \mathrm{~N}$ vs. $1.9 \% \mathrm{~N}$ pre-defoliation), and understory foliage, which composed 1.6 times greater LAI post-defoliation, had an average $\mathrm{N}$ concentration of only $1.3 \% \mathrm{~N}$ (Fig. 1b). By summer 2009, total LAI had nearly recovered to pre-defoliation levels, but 
Table 3. Statistics for ANOVA and contrasts for half-hourly daytime and nighttime net $\mathrm{CO}_{2}$ exchange during the summer (1 June- 31 August; Fig. 2), and daily evapotranspiration, gross ecosystem production, and ecosystem water use efficiency during the summer among stands before disturbance, and within stands among years (Fig. 3). $\mathrm{df}=$ degrees of freedom, $F=$ the value of the $F$ statistic, and $P$ is the significance level for ANOVA analyses. Contrasts for all stands before disturbance are; a: oak vs. mixed and pine, b: mixed vs. pine, c: oak and pine vs. mixed, d: oak vs. pine. Oak stand contrasts are; e: complete defoliation vs. pre- and post-defoliation, f: pre-defoliation vs. postdefoliation. Mixed stand contrasts are; g: pre-disturbance vs. disturbance, h: prescribed burn vs. defoliation. Pine stand contrasts are; i: preand post-disturbance vs. disturbance, j: defoliation vs. prescribed burn. Tukey's Honestly Significant Difference (HSD) tests were used to determine significance levels of each contrast, and $P$ is the significance level for each contrast.

\begin{tabular}{|c|c|c|c|c|c|c|}
\hline Variable/stand & df & $F$ & $P$ & Contrast & HSD & $P$ \\
\hline \multicolumn{7}{|c|}{ Daytime NEE ( $\mu \mathrm{mol} \mathrm{CO} 2 \mathrm{~m}^{-2} \mathrm{~s}^{-1}$ at $\geq 1500 \mu \mathrm{mol} \mathrm{PAR} \mathrm{m}^{-2} \mathrm{~s}^{-1}$ ); Fig. 2} \\
\hline All stands & $2 ; 297$ & 977 & $<0.001$ & $a, b$ & 0.25 & $<0.01,<0.01$ \\
\hline Oak & $3 ; 396$ & 10957 & $<0.001$ & $e, f$ & 0.28 & $<0.01,<0.01$ \\
\hline Mixed & $2 ; 297$ & 6520 & $<0.001$ & $\mathrm{~g}, \mathrm{~h}$ & 0.24 & $<0.01,<0.01$ \\
\hline Pine & $3 ; 396$ & 4793 & $<0.001$ & $\mathrm{i}, \mathrm{j}$ & 0.19 & $<0.01,<0.01$ \\
\hline \multicolumn{7}{|c|}{ Nighttime NEE $\left(\mu \mathrm{mol} \mathrm{CO} \mathrm{CO}^{-2} \mathrm{~s}^{-1}\right)$; Fig. 2} \\
\hline All stands & $2 ; 297$ & 324 & $<0.001$ & $a, b$ & 0.15 & $<0.01,<0.01$ \\
\hline Oak & $3 ; 396$ & 1330 & $<0.001$ & $e, f$ & 0.22 & $<0.01,<0.01$ \\
\hline Mixed & $2 ; 297$ & 128 & $<0.001$ & $\mathrm{~g}, \mathrm{~h}$ & 0.10 & $<0.01,<0.01$ \\
\hline Pine & $3 ; 396$ & 519 & $<0.001$ & $\mathrm{i}, \mathrm{j}$ & 0.15 & $<0.01,<0.01$ \\
\hline \multicolumn{7}{|c|}{ Gross ecosystem production $\left(\mathrm{g} \mathrm{C} \mathrm{m}^{-2}\right.$ day $\left.^{-1}\right) ;$ Fig. 3a } \\
\hline All stands & $2 ; 427$ & 53 & $<0.001$ & $a, b$ & 0.86 & $<0.01,<0.01$ \\
\hline Oak & $3 ; 456$ & 212 & $<0.001$ & $e, f$ & 0.94 & $<0.01,<0.01$ \\
\hline Mixed & $2 ; 273$ & 233 & $<0.001$ & $\mathrm{~g}, \mathrm{~h}$ & 0.79 & $<0.01,<0.01$ \\
\hline Pine & $3 ; 426$ & 29 & $<0.001$ & $\mathrm{i}, \mathrm{j}$ & $0.91,0.75$ & $<0.01,<0.05$ \\
\hline \multicolumn{7}{|c|}{ Evapotranspiration $\left(\mathrm{mm}\right.$ day $\left.^{-1}\right) ;$ Fig. $3 b$} \\
\hline All stands & $2 ; 427$ & 14 & $<0.001$ & $\mathrm{c}, \mathrm{d}$ & 0.43 & $<0.05, \mathrm{~ns}$ \\
\hline Oak & $3 ; 456$ & 43 & $<0.001$ & $e, f$ & 0.56 & $<0.01, \mathrm{~ns}$ \\
\hline Mixed & $2 ; 273$ & 30 & $<0.001$ & $\mathrm{~g}, \mathrm{~h}$ & 0.42 & $<0.01,<0.01$ \\
\hline Pine & $3 ; 367$ & 6 & $<0.01$ & $\mathrm{i}, \mathrm{j}$ & 0.56 & $<0.01,<0.01$ \\
\hline \multicolumn{7}{|c|}{ Ecosystem water use efficiency $\left(\mathrm{g} \mathrm{C} \mathrm{kg} \mathrm{H}_{2} \mathrm{O}^{-1}\right.$ day $\left.^{-1}\right)$; Fig. $3 \mathrm{c}$} \\
\hline All stands & $2 ; 285$ & 14 & $<0.001$ & $a, b$ & 0.23 & $<0.01, \mathrm{~ns}$ \\
\hline Oak & $3 ; 291$ & 52 & $<0.001$ & $e, f$ & 0.31 & $<0.01,<0.01$ \\
\hline Mixed & $2 ; 156$ & 103 & $<0.001$ & $\mathrm{~g}, \mathrm{~h}$ & 0.31 & $\mathrm{~ns},<0.01$ \\
\hline Pine & $3 ; 281$ & 3 & $<0.05$ & $\mathrm{i}, \mathrm{j}$ & 0.24 & $\mathrm{~ns},<0.05$ \\
\hline
\end{tabular}

the understory comprised $23 \%$ of total LAI, compared to $11 \%$ pre-defoliation. Nitrogen mass of canopy and understory foliage in 2009 was 77 and $192 \%$ of pre-disturbance values, respectively.

At the mixed stand, the prescribed fire conducted in February 2006 and herbivory by gypsy moth during the summers of 2006 and 2007 reduced LAI of deciduous species during the growing season, but had relatively little effect on pine foliage in the canopy (Fig. 1a). Nitrogen mass in canopy and understory foliage was reduced in 2006, but by 2007 understory $\mathrm{N}$ mass had nearly recovered to pre-disturbance levels, while canopy $\mathrm{N}$ mass remained relatively low (Fig. 1b).

At the pine stand, partial defoliation of ericaceous shrubs and understory oaks by gypsy moth in 2007 reduced understory LAI and $\mathrm{N}$ mass compared to pre-disturbance periods
(Fig. 1a, b). The prescribed fire conducted in March 2008 was hot enough to scorch some pine foliage, which reduced overstory LAI during the summer to $74 \%$ of pre-disturbance values, and reduced canopy $\mathrm{N}$. The prescribed fire had little effect on understory LAI later in growing season of 2008, because of rapid resprouting of scrub oaks and shrubs. By 2009 , leaf area and $\mathrm{N}$ mass in foliage at the pine stand had recovered to pre-disturbance levels.

\subsection{NEE, GEP, Et and water use efficiency}

Daytime NEE during midday, clear sky conditions $\left(\geq 1500 \mu \mathrm{mol}\right.$ PAR $\left.\mathrm{m}^{-2} \mathrm{~s}^{-1}\right)$ and nighttime NEE in the summer were greater at the oak stand than at the mixed and pine stands before disturbance (Fig. 2, Table 3). Mean daily 


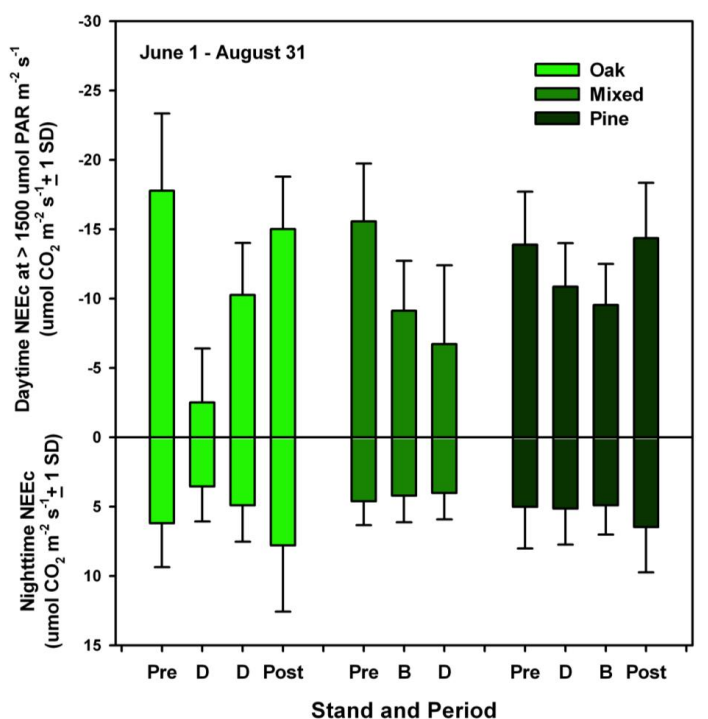

Figure 2. Daytime net $\mathrm{CO}_{2}$ exchange $\left(\mu \mathrm{mol} \mathrm{CO}_{2} \mathrm{~m}^{-2} \mathrm{~s}^{-1}\right)$ at $\geq 1500 \mu \mathrm{mol}$ PAR m${ }^{-2} \mathrm{~s}^{-1}$ and mean nighttime net $\mathrm{CO}_{2}$ exchange during the summer (1 June-31 August) from 2005 to 2009 at the oak, mixed and pine stands. Pre = pre-disturbance, $D=$ defoliation by gypsy moth, $B=$ burned in prescribed fire, Post $=$ post-disturbance. Statistics are in Table 3 .

GEP during the summer also was greater at the oak stand than at the mixed and pine stands, while mean daily Et rates during the summer were greater at the oak and pine stands than at the mixed stand (Fig. 3, Table 3). Daily GEP and Et were highly correlated during the summer months at each stand before disturbance, and when data from the mixed and pine stands were pooled, the slope of the relationship between Et and GEP was greater at the oak stand than at the mixed and pine stands (Fig. 4, Table 4; ANCOVA, $\left.F_{1.393}=157, P<0.001\right)$. Pre-disturbance $\mathrm{WUE}_{\mathrm{e}}$ in the summer also was greater at the oak stand than at the mixed and pine stands (Fig. 3c, Table 3).

During complete defoliation by gypsy moth and second leaf-out of the oak stand during the summer in 2007 half-hourly NEE averaged $-2.5 \mu \mathrm{mol} \mathrm{CO}_{2} \mathrm{~m}^{-2} \mathrm{~s}^{-1}$, which was only $14 \%$ of pre-defoliation rates during midday, and $57 \%$ of pre-defoliation NEE at night (Fig. 2). Mean daily GEP and Et during the summer at the oak stand averaged $3.7 \pm 1.7 \mathrm{~g} \mathrm{C} \mathrm{m}^{-2} \mathrm{day}^{-1}$ and $2.4 \pm 0.9 \mathrm{~mm} \mathrm{day}^{-1}$ (mean $\pm 1 \mathrm{SD}$ ) which represented 35 and $57 \%$ of predefoliation values, respectively. The slope of the relationship between Et and GEP was lower during summer 2007 compared to pre-defoliation periods (Fig. 5a, Table 4). Similarly, $\mathrm{WUE}_{\mathrm{e}}$ was significantly lower in 2007 compared to pre-defoliation periods, averaging only $1.6 \mathrm{~g} \mathrm{C} \mathrm{kg} \mathrm{H}_{2} \mathrm{O}_{\text {day }}{ }^{-1}$ (Fig. 3c, Table 3). Partial defoliation of the oak stand occurred in the summer of 2008, and NEE during mid-day periods averaged $58 \%$ of pre-defoliation rates. By the next growing season in 2009, mid-day NEE had reached $85 \%$

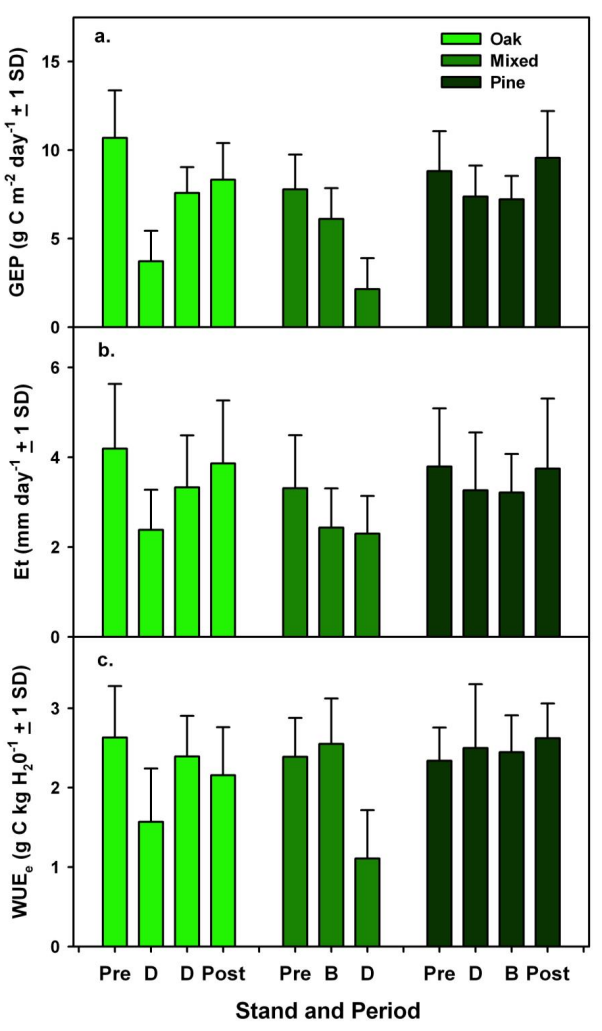

Figure 3. (a) Gross ecosystem productivity (GEP, $\mathrm{g} \mathrm{C} \mathrm{m}^{-2} \mathrm{day}^{-1}$ ), (b) daily evapotranspiration (Et, $\left.\mathrm{mm} \mathrm{day}^{-1}\right)$, and (c) ecosystem water use efficiency (WUE, $\mathrm{g} \mathrm{C} \mathrm{mm} \mathrm{Et} \mathrm{day}^{-1}$ ) calculated for the oak stand from 2005 to 2009 , the mixed stand from 2005 to 2007, and the pine stand from 2005 to 2009 during the summer. WUE was calculated from the ratio of GEP to Et for dry canopy conditions. Pre $=$ pre-disturbance, $D=$ defoliation by Gypsy moth, $B=$ burned in prescribed fire, Post $=$ post-disturbance. Statistics are in Table 3.

of pre-defoliation rates (Fig. 2). Nighttime NEE during the second year following complete defoliation was greater than pre-defoliation periods, and corresponded with mortality of mature oaks and wet conditions in 2009. It is notable that many of the oaks that died had basidiocarps of honey fungus (Armillaria sp.) around their bases in fall 2009. Daily GEP during the summer was 71 and $78 \%$ of pre-defoliation levels, and Et had increased to 79 and $92 \%$ of pre-defoliation levels in 2008 and 2009, respectively (Fig. 3, Table 3). $W^{2} E_{e}$ averaged $2.3 \mathrm{~g} \mathrm{C} \mathrm{kg} \mathrm{H}_{2} \mathrm{O}_{\text {day }}{ }^{-1}$ during the summers of 2008 and 2009 , which was $86 \%$ of pre-defoliation values.

Following the prescribed burn in early spring of 2006 at the mixed stand, mid-day NEE during the summer during near clear sky conditions was $59 \%$ of pre-disturbance values, and during complete defoliation of deciduous species by gypsy moth in 2007, midday NEE average $6.7 \mu \mathrm{mol}$ $\mathrm{CO}_{2} \mathrm{~m}^{-2} \mathrm{~s}^{-1}$, which was only $43 \%$ of pre-disturbance values (Fig. 2, Table 3). Nighttime NEE during the summer was nearly unaffected by either disturbance. Daily GEP was $79 \%$ of pre-disturbance values during the summer following the 
Table 4. Parameter values and statistics for the relationship between daily evapotranspiration and gross ecosystem productivity from 1 June to 31 August for the oak vs. mixed and pine stands in 2005 before disturbance (Fig. 4), the oak stand from 2005 to 2009 (Fig. 5 a), the mixed stand from 2005 to 2007 (Fig. 5b), and the pine stand from 2005 to 2009 (Fig. 5c). Data were fitted to GEP $=\alpha(1-\exp (-\beta$ (Et))). Parameter values are means \pm 1 standard error, $r^{2}$ is the value of the Pearson's product moment coefficient, $F$ is the value of the $F$ statistic, and $P$ is the significance level of the ANOVA analyses for each model.

\begin{tabular}{lccccc}
\hline Stand/period & $\alpha$ & $\beta$ & $r^{2}$ & $F$ & $P$ \\
\hline \multicolumn{7}{c}{ Oak vs. mixed and pine stands (shown in Fig. 4) } \\
\hline Oak & $15.54 \pm 0.70$ & $0.34 \pm 0.03$ & 0.79 & 335 & $<0.0001$ \\
Mixed, pine & $14.29 \pm 0.74$ & $0.25 \pm 0.02$ & 0.83 & 722 & $<0.0001$ \\
\hline \multicolumn{7}{c}{ Oak (shown in Fig. 5a) } \\
\hline Pre-defoliation & $15.97 \pm 0.69$ & $0.29 \pm 0.03$ & 0.72 & 476 & $<0.0001$ \\
Defoliation 2007 & $12.93 \pm 6.30$ & $0.15 \pm 0.09$ & 0.51 & 96 & $<0.0001$ \\
Defoliation 2008 & $10.33 \pm 0.56$ & $0.43 \pm 0.05$ & 0.47 & 81 & $<0.0001$ \\
Post-defoliation & $11.44 \pm 0.53$ & $0.37 \pm 0.04$ & 0.74 & 264 & $<0.0001$ \\
\hline \multicolumn{7}{c}{ Mixed (shown in Fig. 5b) } & & \\
\hline Pre-disturbance & $11.75 \pm 0.60$ & $0.36 \pm 0.04$ & 0.81 & 378 & $<0.0001$ \\
Prescribed fire & $9.64 \pm 0.12$ & $2.40 \pm 0.31$ & 0.63 & 158 & $<0.0001$ \\
Defoliation & $-0.32 \pm 0.46$ & $1.07 \pm 0.19$ & 0.25 & 32 & $<0.001$ \\
\hline \multicolumn{7}{c}{ Pine (shown in Fig. 5c) } & & \\
\hline Pre-disturbance & $13.42 \pm 0.53$ & $0.28 \pm 0.02$ & 0.81 & 671 & $<0.0001$ \\
Partial defoliation & $9.70 \pm 0.53$ & $0.50 \pm 0.05$ & 0.83 & 436 & $<0.0001$ \\
Prescribed fire & $9.59 \pm 0.36$ & $0.49 \pm 0.05$ & 0.70 & 208 & $<0.0001$ \\
Post-disturbance & $13.57 \pm 0.50$ & $0.37 \pm 0.06$ & 0.85 & 530 & $<0.0001$ \\
\hline
\end{tabular}

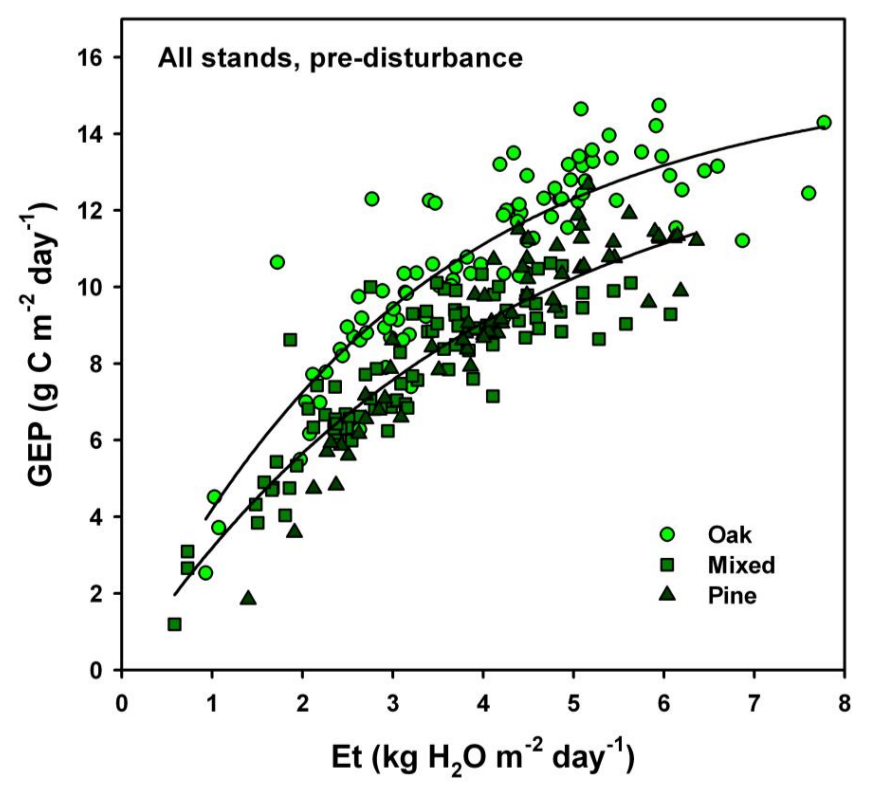

Figure 4. The relationship between daily evapotranspiration $\left(E t, \mathrm{mmday}^{-1}\right.$ ) and daily gross ecosystem production (GEP, $\mathrm{g} \mathrm{C} \mathrm{m}^{-2} \mathrm{day}^{-1}$ ) for the oak, mixed and pine stands from 1 June to 31 August 2005, before disturbance. Statistics are in Table 4. prescribed fire in 2006 , and only $28 \%$ of pre-disturbance values during and following defoliation of deciduous species by gypsy moth in 2007. Summer daily Et was 73 and $69 \%$ of pre-disturbance values in 2006 and 2007, respectively (Fig. 3b, Table 3). Slopes for the relationship between GEP and Et were similar pre- and post-prescribed burn, but the intercept for this relationship was lower during defoliation by gypsy moth in 2007 compared to pre-defoliation periods (Fig. 5). Similarly, $\mathrm{WUE}_{\mathrm{e}}$ at the mixed stand was similar pre- and post-prescribed burn, but significantly lower during defoliation in 2007 , averaging only $1.1 \mathrm{~g} \mathrm{C} \mathrm{kg} \mathrm{H}_{2} \mathrm{O}_{\text {day }}{ }^{-1}$ (Fig. 3c, Table 3).

At the pine stand, midday NEE during clear sky conditions in the summer was $79 \%$ of pre-disturbance values during defoliation of the understory by gypsy moth in 2007. During the first growing season following the prescribed burn conducted in March 2008, midday NEE averaged $-9.5 \mu \mathrm{mol}$ $\mathrm{CO}_{2} \mathrm{~m}^{-2} \mathrm{~s}^{-1}$, which was $69 \%$ of pre-disturbance values (Fig. 2). By the next growing season following the prescribed burn, mid-day NEE had recovered to pre-disturbance values (Fig. 2, Table 3). Nighttime NEE at the pine stand was apparently unaffected by either disturbance. Summer daily GEP averaged $84 \%$ of pre-disturbance values during defoliation of deciduous species by gypsy moth in 2007, and $82 \%$ following the prescribed burn in 2008 (Fig. 3a, Table 3). Post-disturbance, daily GEP in 2009 averaged 9.6 


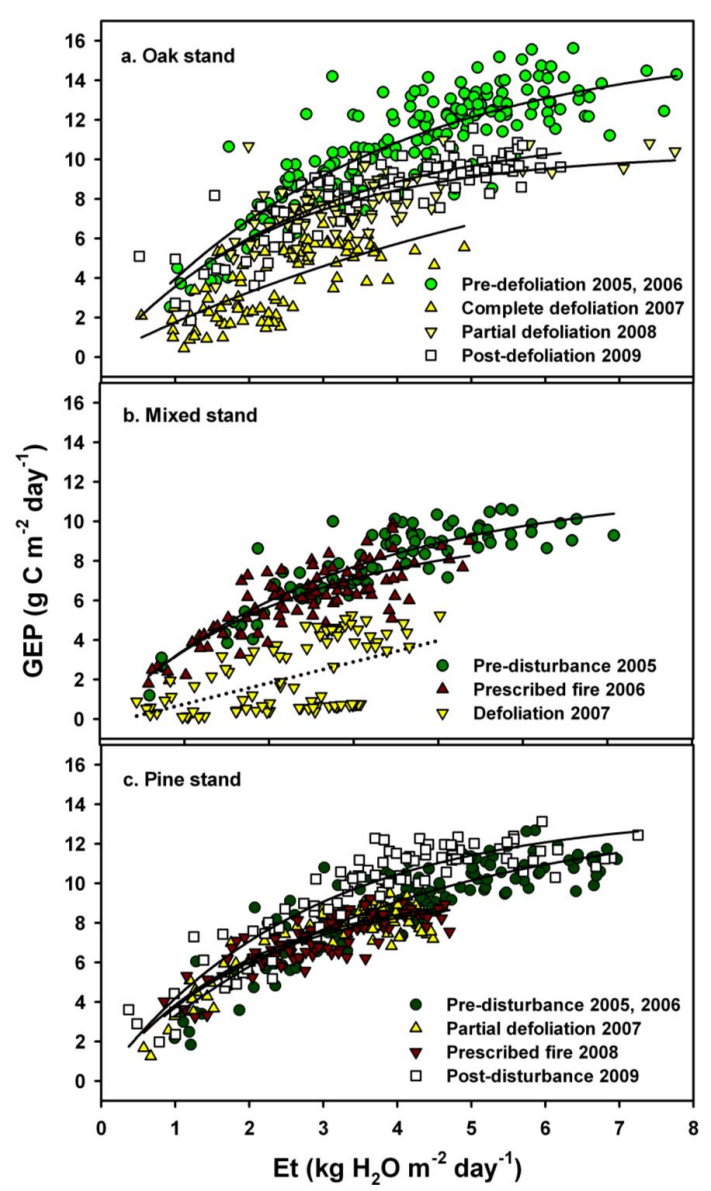

Figure 5. The relationship between daily evapotranspiration $\left(\mathrm{Et}, \mathrm{mmday}^{-1}\right)$ and daily gross ecosystem production (GEP, $\mathrm{g} \mathrm{C} \mathrm{m}^{-2} \mathrm{day}^{-1}$ ) for the (a) oak stand from 1 June to 31 August for 2005-2009, the (b) mixed stand from 1 June to 31 August for 2005-2007, and the (c) pine stand from 1 June to 31 August for 2005-2009. Statistics are in Table 4.

$\pm 2.6 \mathrm{~g} \mathrm{C} \mathrm{m}^{-2} \mathrm{day}^{-1}$, representing $109 \%$ of pre-disturbance values. Summer daily Et averaged 85,83 and $99 \%$ of predisturbance levels in 2007, 2008 and 2009, respectively (Fig. 3b, Table 3). The relationship between daily Et and GEP was similar pre- and post-disturbance (Fig. 5c, Table 4), and WUE $_{\mathrm{e}}$ was unaffected by defoliation of deciduous species in the understory or the prescribed burn when compared to pre-disturbance values (Fig. 3, Table 3).

The relationship between annual maximum $\mathrm{N}$ mass in foliage and mean daily GEP during the summer months was significant at the oak stand, accounting for $84 \%$ of the variability in GEP during the summer (Table 5). When data for the oak and mixed stands were pooled, maximum $\mathrm{N}$ mass in foliage accounted for $79 \%$ of the variability in mean daily GEP during the summer. In contrast, only $46 \%$ of the variability in mean daily GEP during the summer was accounted for by annual maximum $\mathrm{N}$ in foliage at the pine stand (Table 5). Daily Et during the summer was significantly corre- lated with maximum annual LAI at the oak stand, and at the mixed and pine stands when data were pooled (see also Clark et al., 2012). The relationship between maximum $\mathrm{N}$ mass in foliage and mean daily $\mathrm{WUE}_{\mathrm{e}}$ was nearly significant at the oak stand, and at the oak and mixed stand when data were pooled (Table 5).

Annual estimates of NEE, $R_{\text {eco }}$, GEP and Et for the three upland forest stands are shown in Table 6. Over all years measured, the oak and mixed stands were only weak sinks for $\mathrm{CO}_{2}$. Variation in NEE was greatest at the oak stand, ranging from a sink averaging approx. $-170 \mathrm{~g} \mathrm{C} \mathrm{m}^{-2} \mathrm{yr}^{-1}$ before defoliation to a source of $248 \mathrm{~g} \mathrm{C} \mathrm{m}^{-2} \mathrm{yr}^{-1}$ during the year of complete defoliation by gypsy moth in 2007 . The pinedominated stand was a moderate sink for $\mathrm{CO}_{2}$, but when consumption estimated from pre- and post-burn samples of the understory and forest floor (approx. $441 \mathrm{~g} \mathrm{C} \mathrm{m}^{-2}$ ) was incorporated into the longer term $\mathrm{C}$ balance, the estimated average $\mathrm{C}$ sink strength was only $-30 \mathrm{~g} \mathrm{C} \mathrm{m}^{-2} \mathrm{yr}^{-1}$. Variation in annual $R_{\text {eco }}$ was relatively low at the mixed and pine stands, but the range in annual values was $550 \mathrm{~g} \mathrm{~m}^{-2} \mathrm{yr}^{-1}$ at the oak dominated stand, representing a coefficient of variation of $44 \%$ of mean annual $R_{\text {eco. }}$. The greatest reduction in GEP occurred during the year of complete defoliation at the oak stand, and both defoliation and prescribed burns reduced annual GEP and Et at the mixed and pine stands (Table 6). The greatest reduction in annual Et occurred at the mixed stand, where both disturbances had occurred sequentially.

\section{Discussion}

Gypsy moth are now ubiquitous in forests of the MidAtlantic region. Approximately $24 \%$ of forests in the region are classified as highly susceptible to gypsy moth, and $7 \%$ are classified as extremely susceptible (Leibhold, 2003, http://www.fia.fs.fed.us/). In New Jersey, 36 and $15 \%$ of forests are classified as highly and extremely susceptible to gypsy moth defoliation, respectively. Although recent surveys indicate that gypsy moth populations have largely crashed since 2009 in the Mid-Atlantic region, populations can exhibit cyclical dynamics, with 4-5-year and 8-10-year cycles co-occurring (Allstadt et al., 2013). During the peak of the last outbreak, approximately $20 \%$ of upland forests were defoliated in the PNR in 2007 (http://www.state.nj.us/ agriculture/divisions/pi/pdf/07defoliationtable.pdf). In many oak-dominated stands, LAI and $\mathrm{N}$ in foliage during the early summer were reduced to levels characterizing the dormant season. In pine-dominated stands, defoliation of pines by gypsy moth was typically minor, but foliage of sub-canopy oaks and shrubs in the understory was susceptible to defoliation. When defoliation is severe and occurs over multiple years, such as in oak-dominated and mixed stands in the PNR from 2006 to 2008, invasive insects can have major, and likely long-term, impacts on canopy $\mathrm{N}$ pools. In addition to the immediate reduction in leaf area and canopy $\mathrm{N}$ 
Table 5. Parameters and statistics for the relationship between maximum canopy and understory $\mathrm{N}$ content and mean daily gross ecosystem productivity, and between maximum LAI and mean daily Et during the summer from 1 June to 31 August. Data were fitted to GEP $=\alpha$ $($ canopy $\mathrm{N})+\beta$. Parameter values are means \pm 1 standard error, $r^{2}$ is the value of the Pearson's product moment coefficient, $F$ is the value of the $F$ statistic, and $P$ is the significance level of the ANOVA analyses for each model. Values are for the oak stand from 2005 to 2009 , the mixed stand from 2005 to 2007 , and the pine stand from 2005 to 2009 .

\begin{tabular}{lccccc}
\hline Stand & $\alpha$ & $\beta$ & $r^{2}$ & $F$ & $P$ \\
\hline \multicolumn{4}{c}{ Nitrogen in foliage $\left(\mathrm{g} \mathrm{N} \mathrm{m}^{-2}\right)$ and daily gross ecosystem production $\left(\mathrm{g} \mathrm{C} \mathrm{m}^{-2}\right.$ day $\left.^{-1}\right)$} \\
\hline Oak & $1.50 \pm 0.32$ & $0.58 \pm 1.71$ & 0.84 & 22.6 & $<0.05$ \\
Oak, mixed & $1.64 \pm 0.32$ & $-0.49 \pm 1.58$ & 0.79 & 27.0 & $<0.01$ \\
Pine & $1.22 \pm 0.58$ & $3.49 \pm 2.38$ & 0.46 & 4.4 & $\mathrm{~ns}$ \\
\hline \multicolumn{7}{c}{ Leaf area index $\left(\mathrm{m}^{2} \mathrm{~m}^{-2}\right)$ and evapotranspiration $\left(\mathrm{mm} \mathrm{day}^{-1}\right)$} \\
\hline Oak & $0.72 \pm 0.15$ & $0.84 \pm 0.62$ & 0.81 & 18.6 & $<0.05$ \\
Mixed, pine & $0.62 \pm 0.12$ & $0.20 \pm 0.58$ & 0.80 & 29.8 & $\mathrm{~ns}$ \\
Pine & $0.43 \pm 0.20$ & $1.31 \pm 1.06$ & 0.46 & 4.4 & $<0.01$ \\
\hline Nitrogen in foliage $\left(\mathrm{g} \mathrm{N} \mathrm{m}^{-2}\right)$ and ecosystem water use efficiency $\left(\mathrm{g} \mathrm{C} \mathrm{m}^{-2} \mathrm{~kg} \mathrm{H}_{2} \mathrm{O} \mathrm{day}^{-1}\right)$ \\
\hline Oak & $0.26 \pm 0.09$ & $0.93 \pm 0.50$ & 0.63 & 7.8 & $<0.08$ \\
Oak, mixed & $0.26 \pm 0.11$ & $0.92 \pm 0.58$ & 0.33 & 4.5 & $<07$ \\
\hline
\end{tabular}

in defoliated stands, a second mechanism leading to the reduction of $\mathrm{N}$ in foliage in oak stands was selective herbivory and subsequent mortality of black oak, which initially had the highest mean foliar $\mathrm{N}$ content (approximately $2.1 \% \mathrm{~N}$ ) in our study. By 2009, many of the mature black oaks had either died or had moderate to severe crown damage, which reduced their leaf area. In contrast, chestnut oak, which had a lower $\mathrm{N}$ content in foliage (approximately $1.8 \% \mathrm{~N}$ ), had relatively low mortality and less canopy damage, and accounted for a greater amount of canopy leaf area following defoliation. A third factor contributing to the overall reduction of the foliar $\mathrm{N}$ pool is the response of the understory to gap formation caused by overstory defoliation and subsequent mortality. Understory LAI had increased 2-fold over pre-defoliation periods by 2008 , and this pattern has persisted through 2013, 6 years following complete defoliation of the oak stand. This has led to a much larger contribution of understory foliage to stand LAI, however, shrub foliage had consistently lower $\mathrm{N}$ content than canopy oaks and therefore did not completely replace the $\mathrm{N}$ lost from the canopy. Overall, changes in canopy composition and increased LAI in the understory resulted in lower $\mathrm{N}$ content in foliage in severely defoliated stands.

Lovett et al. $(2002,2006)$ have shown that defoliation by invasive insects can cause large $\mathrm{N}$ transfers within the forest, but indicated that overall leaching losses are relatively minor. Our results suggest that recovery from internal transfers of $\mathrm{N}$ attributed to defoliation by gypsy moth may require a number of years, because of the time required to restore canopy foliar nutrient pools. As the defoliation in our oak study area has caused mortality somewhat selectively by species, we expect long-term shifts in species composition, and resultant changes to $\mathrm{N}$ mass in canopy foliage. This finding is consistent with results published by Medvigy et al. (2012), who used the ED2 model to explore the interactive effects of herbivory and drought on long-term carbon dynamics and found reduced GEP and forest productivity over time following intensive, repeated defoliation events (Medvigy et al., 2012). Lack of recovery of foliar $\mathrm{N}$ pools in the canopy may also predispose stands to be more sensitive to other stresses. For example, daytime NEE at the oak stand was apparently more sensitive to summer drought that occurred in 2010 compared to pre-disturbance periods, and further mortality of overstory oaks occurred (Renninger et al., 2014b).

The effects of prescribed burning on LAI and canopy $\mathrm{N}$ content at the mixed and pine stands were relatively less intense than defoliation at the oak and mixed stands. Pitch and shortleaf pines have epicormic meristems that can sprout rapidly following disturbance, thus overstory needle recovery can occur rapidly. Although many aboveground stems of shrubs and understory oaks were killed during the burns, they can readily resprout from belowground stems following fire and their leaf area recovered quickly (Clark et al., 2014). Prescribed burning also apparently had little effect on $W_{U E}$. A potential explanation for this observation is also related to stand nutrient dynamics, because it is likely that the burn pyro-mineralized stored nutrients such as phosphorus and calcium in the forest floor, and these became available to canopy and understory vegetation following the prescribed fire (Gray and Dighton, 2006, 2009).

Variation in foliar $\mathrm{N}$ mass and LAI were major biotic factors affecting GEP and Et during our study. $\mathrm{N}$ mass in foliage was significantly correlated with summer daily GEP at the oak and mixed stands, both of which had a significant 
Table 6. Annual net $\mathrm{CO}_{2}$ exchange (NEE), ecosystem respiration $\left(R_{\mathrm{eco}}\right)$, gross ecosystem production $\left(\mathrm{GEP}, \mathrm{g} \mathrm{C} \mathrm{m}^{-2} \mathrm{yr}^{-1}\right)$, evapotranspiration $\left(\mathrm{Et}, \mathrm{mm}_{\mathrm{year}}{ }^{-1}\right)$, and the ratio of GEP to ET for the oak, mixed, and pine stands. Percent filtered half-hourly NEE data for each year used to calculate annual NEE, $R_{\text {eco }}$ and GEP are shown in the first column. Values in parentheses for NEE are maximum deviations from annual values as a result of gap filling using \pm 1 standard error of daytime or nighttime parameters.

\begin{tabular}{|c|c|c|c|c|c|c|}
\hline Stand, Period & $\begin{array}{r}\text { Percent } \\
\text { NEE data }\end{array}$ & NEE & $\begin{array}{c}R_{\mathrm{eco}} \\
\left(\mathrm{gC} \mathrm{m}^{-2} \mathrm{yr}^{-1}\right)\end{array}$ & GEP & $\begin{array}{c}\mathrm{Et} \\
\left(\mathrm{mm} \mathrm{yr}^{-1}\right)\end{array}$ & $\mathrm{GEP} / \mathrm{Et}$ \\
\hline \multicolumn{7}{|l|}{ Oak } \\
\hline 2005 & 49 & $-185(21)$ & 1285 & 1470 & 616 & 2.39 \\
\hline 2006 & 52 & $-140(23)$ & 1395 & 1535 & 677 & 2.27 \\
\hline 2007, defoliated & 54 & $246(11)$ & 972 & 726 & 442 & 1.64 \\
\hline 2008, defoliated & 56 & $-77(18)$ & 1066 & 1143 & 637 & 1.79 \\
\hline 2009 & 55 & $-9(25)$ & 1523 & 1532 & 699 & 2.19 \\
\hline Mean $\pm 1 \mathrm{SD}$ & & $-33 \pm 169$ & $1248 \pm 228$ & $1281 \pm 350$ & $614 \pm 102$ & \\
\hline \multicolumn{7}{|l|}{ Mixed } \\
\hline 2005 & 35 & $-99(17)$ & 1068 & 1167 & 607 & 1.92 \\
\hline 2006, burned & 42 & 37 (14) & 1111 & 1073 & 452 & 2.37 \\
\hline 2007, defoliated & 45 & $20(20)$ & 1012 & 992 & 419 & 2.37 \\
\hline Mean \pm 1 SD & & $-14 \pm 74$ & $1064 \pm 50$ & $1077 \pm 88$ & $493 \pm 100$ & \\
\hline \multicolumn{7}{|l|}{ Pine } \\
\hline 2005 & 38 & $-178(24)$ & 1445 & 1623 & 761 & 2.13 \\
\hline 2006 & 47 & $-165(17)$ & 1477 & 1642 & 757 & 2.17 \\
\hline 2007, defoliated & 58 & $-40(7)$ & 1362 & 1402 & 593 & 2.36 \\
\hline 2008, burned & 60 & $-48(26)$ & 1329 & 1377 & 617 & 2.23 \\
\hline 2009 & 55 & $-158(18)$ & 1597 & 1755 & 764 & 2.30 \\
\hline Mean \pm 1 SD & & $-118 \pm 68$ & $1442 \pm 105$ & $1560 \pm 164$ & $699 \pm 86$ & \\
\hline
\end{tabular}

Note: $\mathrm{NEE}_{c}$ for 2005 to 2007 have been previously reported in Clark et al. (2010), and Et values have been previously reported in Clark et al. (2012).

component of deciduous species (Skowronski et al., 2007; Clark et al., 2010). On an annual basis, however, GEP was greatest at the pine stand, which had the longest leaf area display when integrated throughout the year and the highest GEP during spring and summer; the relationship between canopy $\mathrm{N}$ content and daily GEP during the summer was weaker at this stand. Clark et al. (2012) reported that LAI was strongly related to daily Et during the summer at all three stands. Interestingly, mean daily $\mathrm{WUE}_{\mathrm{e}}$ during the summer was only weakly correlated with foliar N content or LAI at the oak or mixed stands, although this relationship may become significant using a longer term data set.

Before each disturbance, daily NEE, GEP and $\mathrm{WUE}_{\mathrm{e}}$ during the summer were greater at the oak stand than at the mixed or pine-dominated stands. Previously reported summer NEE light response curves support this result (Clark et al., 2010), as do leaf-level measurements of oak vs. pine foliage (Schäfer, 2011; Renninger et al., 2013, 2014a). Predisturbance daily GEP rates during the summer at the three stands in the PNR were intermediate between published rates of undisturbed forest in more southerly sites on the Atlantic coastal plain (ca. $8-13 \mathrm{~g} \mathrm{C} \mathrm{m}^{-2} \mathrm{day}^{-1}$; Clark et al., 1999, 2004; Stoy et al., 2006; Noormets et al., 2010) and stands further to the north (ca. 4-10 g C-2 day ${ }^{-1}$; Mkhebela et al., 2009; Brümmer et al., 2012). Pre-disturbance mean daily Et at the oak and pine-dominated stands stand during the summer $\left(4.2 \pm 1.5 \mathrm{~mm}\right.$ and $\left.3.9 \pm 1.3 \mathrm{day}^{-1}\right)$ were within the range of values reported from other temperate broadleaved and conifer-dominated forests (reviewed in Clark et al., 2012).

Highly significant relationships between GEP and Et have been noted at a wide range of timescales (e.g., daily to annual) in many forests. For example, Law et al. (2002) reported a significant relationship between monthly Et (expressed as Et/precipitation) and GEP for a wide range of Ameriflux sites, and Brümmer et al. (2012) reported significant relationships between Et and GEP across a range of forests in Canada. Pre-disturbance WUE $_{\mathrm{e}}$ values for stands in the Pinelands were at the low end of values reported from temperate hardwood forests, rather they were more similar to closed-canopy conifer dominated and boreal forests (Law et al., 2002; Kuglitsch et al., 2008; Brümmer et al., 2012). For example, Law et al. (2002) reported values of up to $6 \mathrm{~g} \mathrm{C} \mathrm{kg}^{-1} \mathrm{H}_{2} \mathrm{O}$ for monthly $\mathrm{WUE}_{\mathrm{e}}$ in temperate hardwood forests, while closed canopy stands in Boreal forest and conifer-dominated stands had $\mathrm{WUE}_{\mathrm{e}}$ values ranging from 
2.0 to $3.6 \mathrm{~g} \mathrm{C} \mathrm{kg}^{-1} \mathrm{H}_{2} \mathrm{O}$ (Mkhebela et al., 2009; Brümmer et al., 2012; Vickers et al., 2012). On the Atlantic coastal plain, $\mathrm{WUE}_{\mathrm{e}}$ of a rotation age slash pine (Pinus elliottii Engelm.) plantation on sandy soils in N. Florida averaged $2.7 \mathrm{~g} \mathrm{C} \mathrm{kg}^{-1} \mathrm{H}_{2} \mathrm{O}$ (reanalyzed data from Clark et al., 2004).

Defoliation by Gypsy moth reduced both daytime and nighttime NEE at the oak and mixed stands compared to pre-disturbance periods. Clark et al. (2010) showed that the relationship between air or soil temperature and half-hourly nighttime NEE during defoliation in the summer during 2007 was significantly different and that mean nighttime NEE was lower when compared to undisturbed periods, despite the fact that soil temperatures were ca. $2{ }^{\circ} \mathrm{C}$ higher, while air temperature was similar to pre-disturbance periods. As a result, annual $R_{\text {eco }}$ was lower in 2007 and 2008 compared to pre-disturbance years. Following this period of reduced nighttime NEE, higher rates at nighttime half-hourly and annual timescales corresponded with tree mortality and wet conditions in 2009 (Renninger et al., 2014b). Annual GEP at the oak stand had approached pre-disturbance values by 2009 , but relatively high $R_{\text {eco }}$ lagged complete defoliation by 2 years, and resulted in very low annual NEE in 2009. When integrated over 2007-2013, however, annual $R_{\text {eco }}$ averaged $1394 \pm 274$ (mean $\pm 1 \mathrm{SD}$ ) $\mathrm{g} \mathrm{C} \mathrm{m}^{-2} \mathrm{yr}^{-1}$ at the oak stand, thus the long-term average following defoliation was more similar to pre-disturbance values, which averaged $1340 \mathrm{~g} \mathrm{C} \mathrm{m}^{-2} \mathrm{yr}^{-1}$. The relatively high variability in nighttime NEE and annual $R_{\text {eco }}$ contrasts somewhat with results reported from other disturbed forests on the Atlantic coastal plain (e.g., Amiro et al., 2010). For example, following clearcutting of a slash pine plantation in N. Florida, variation in $R_{\text {eco }}$ was only $304 \mathrm{~g} \mathrm{C} \mathrm{m}^{-2} \mathrm{yr}^{-1}$ pre- and post-harvest, representing a coefficient of variation of $14 \%$ of mean annual values, despite major changes in biomass and detrital pools on the forest floor and soil disturbance associated with site preparation (Clark et al., 2004; Binford et al., 2006).

Defoliation by Gypsy moth reduced GEP and $\mathrm{WUE}_{\mathrm{e}}$ at the oak and mixed stands, but $\mathrm{WUE}_{\mathrm{e}}$ values were not as low as those reported following clear-cutting or severe wildfires in other forest ecosystems (Clark et al., 2004; Mkhebela et al., 2009; Dore et al., 2010). For example, following clearcutting of the slash pine plantation noted above, GEP was initially minimal and recovered relatively slowly, while Et was similar to pre-harvest rates because of partial flooding of the stand (Gholz and Clark, 2002; Clark et al., 2004). WUE $_{\mathrm{e}}$ averaged $0.7 \mathrm{~g} \mathrm{C} \mathrm{kg} \mathrm{H}_{2} \mathrm{O}^{-1}$ during the first year following harvest, and had increased to $1.7 \mathrm{~g} \mathrm{C} \mathrm{kg} \mathrm{H}_{2} \mathrm{O}^{-1}$ during the second year, compared to a pre-harvest value of $2.7 \mathrm{~g} \mathrm{C} \mathrm{kg} \mathrm{H}_{2} \mathrm{O}^{-1}$. In a ponderosa pine (P. ponderosa P. \& C. Lawson) stand that had burned 10 years previously in a severe wildfire, GEP was only $43 \%$ of values at an undisturbed ponderosa pine stand, while Et had recovered to a greater extent, averaging 2.0 compared to $2.4 \mathrm{~mm}_{\text {day }}{ }^{-1}$ at the undisturbed stand during the summer (Dore et al., 2010). Monthly $\mathrm{WUE}_{\mathrm{e}}$ during the summer averaged ca.
$1.2 \mathrm{~g} \mathrm{C} \mathrm{kg} \mathrm{H}_{2} \mathrm{O}^{-1}$ at the stand that had been burned severely, and $1.7 \mathrm{~g} \mathrm{C} \mathrm{kg} \mathrm{H}_{2} \mathrm{O}^{-1}$ at the undisturbed stand over the 2 years measured. Mkhabela et al. (2009) summarized the effects of harvesting and wildfires in boreal forest in Canada using a chronosequence approach, and reported that recovery of GEP was slower than Et. Two to three years following harvest of a jack pine (Pinus banksiana Lamb.) stand, WUE $_{\mathrm{e}}$ averaged only $0.6 \mathrm{~g} \mathrm{C} \mathrm{kg} \mathrm{H}_{2} \mathrm{O}^{-1}$, and they estimated that recovery to pre-disturbance values would not occur until ca. 15 years following harvest. Similarly, $\mathrm{WUE}_{\mathrm{e}}$ averaged $1.4 \mathrm{~g} \mathrm{C} \mathrm{kg} \mathrm{H}_{2} \mathrm{O}^{-1} 6$ to 7 years following a severe wildfire, compared to $2.2 \mathrm{~g} \mathrm{C} \mathrm{kg} \mathrm{H}_{2} \mathrm{O}^{-1}$ in an undisturbed stand. Overall, our results suggest that $\mathrm{WUE}_{\mathrm{e}}$ in forests following nonstand replacing disturbance is dependent on the type of disturbance and the impact on $\mathrm{N}$ status of canopy and understory foliage, in addition to time since disturbance. Defoliation by gypsy moth had a stronger effect on $\mathrm{WUE}_{\mathrm{e}}$, with consistently lower daily values occurring during the summer of the year when defoliation occurred at the oak and mixed stands, while $\mathrm{WUE}_{\mathrm{e}}$ was largely unaffected by prescribed burning at the mixed and pine stands.

Using the relationships between $\lambda E$ and available energy ( $R_{\text {net }}-G$-storage terms) for non-defoliated periods in Clark et al. (2012) and continuous meteorological data for 2005-2009, we estimated that annual Et in the absence of gypsy moth or fire would have averaged $661 \pm 32$ and $757 \pm 6 \mathrm{~mm} \mathrm{yr}^{-1}$ at the oak and pine stands, respectively. When compared to Et measured at each site, 5-year averages differed by only 47 and $59 \mathrm{~mm}$ at the oak and pine stands, respectively, representing a $9 \%$ decrease in Et. Assuming an average precipitation depth of $1159 \mathrm{~mm} \mathrm{yr}^{-1}$ across all upland forests, we estimated that groundwater recharge was approximately 9 and $15 \%$ higher during and following disturbance at each stand (Schäfer et al., 2013). Similarly, using relationships between PAR and daytime NEE, and between air or soil temperature and nighttime NEE of undisturbed years, we estimated that annual NEE at the oak stand in the absence of gypsy moth defoliation potentially averaged $-191 \pm 40 \mathrm{~g} \mathrm{C} \mathrm{m}^{-2} \mathrm{yr}^{-1}$ from 2005 to 2009 , and that potential $R_{\text {eco }}$ and GEP averaged $1276 \pm 76$ and $1467 \pm 67 \mathrm{~g} \mathrm{C} \mathrm{m}^{-2} \mathrm{yr}^{-1}$ over the same period, respectively. In contrast, our measured average annual NEE was only $17 \%$ of the potential value that would have occurred in the absence of gypsy moth at the oak stand for 2005-2009. Annual NEE measured at the oak stand in $2010,2011,2012$, and 2013 was $-15,-49,-84$, and $-59 \mathrm{~g} \mathrm{C} \mathrm{m}^{-2} \mathrm{yr}^{-1}$, indicating that recovery from complete defoliation takes at least 6 years. Potential and estimated annual GEP differed by an average of $186 \mathrm{~g} \mathrm{C} \mathrm{m}^{-2} \mathrm{yr}^{-1}$ at the oak stand. $R_{\text {eco }}$ estimated for the oak stand over 2005-2009 was only $28 \mathrm{~g} \mathrm{C} \mathrm{m}^{-2} \mathrm{yr}^{-1}$ less than potential values, supporting the observation that $R_{\text {eco }}$ is largely invariant with disturbance over longer timescales (e.g., Amiro et al., 2010). At the pine stand, we estimated that annual NEE in the absence of Gypsy moth defoliation and prescribed burning 
potentially averaged $-142 \pm 40 \mathrm{~g} \mathrm{C} \mathrm{m}^{-2} \mathrm{yr}^{-1}$ from 2005 to 2009 , and that potential $R_{\text {eco }}$ and GEP were $1437 \pm 39$ and $1579 \pm 65 \mathrm{~g} \mathrm{C} \mathrm{m}^{-2} \mathrm{yr}^{-1}$, respectively. Measured average annual NEE was $76 \%$ of the potential value that would have occurred in the absence of disturbance, but when consumption losses due to the prescribed burn are included, annual NEE was only $14 \%$ of the potential value at the pine stand for 2005-2009. Similarly, potential and estimated annual GEP differed by an average of only $19 \mathrm{~g} \mathrm{C} \mathrm{m}^{-2} \mathrm{yr}^{-1}$ at the pine stand. Although these calculations assume that $\lambda E$, NEE and GEP measured at our sites during pre-disturbance periods characterize potential rates during later years in the absence of disturbance, they illustrate the magnitude of the impact that gypsy moth defoliation and prescribed burning can have on stand carbon dynamics, while having relatively little effect on Et and groundwater recharge (Schäfer et al., 2013).

Our results illustrate two important points; forest $\mathrm{C}$ dynamics and especially NEE are apparently much more sensitive to non-stand replacing disturbances than Et, and disturbances that result in large $\mathrm{N}$ transfers within stands may have long-term impacts on rates of GEP and NEE at half-hourly to annual timescales. When evaluating tradeoffs between hydrologic resources and forest carbon dynamics, forest managers may incorrectly assume that disturbance that results in minimal impact on hydrological cycling (such as estimated from USGS weir data) would also result in minimal impact on carbon sequestration rates, when in fact the size of the carbon sink may actually be quite small. It is also clear that if climate change results in a greater likelihood of insect invasions, fire or other perturbations, and we consider temporal variation in canopy $\mathrm{N}$ status and $\mathrm{WUE}_{\mathrm{e}}$ with disturbance, our ability to predict interactions between carbon and hydrologic cycles in the future will improve.

\section{Conclusions}

Eddy covariance and biometric measurements made in three stands in the Pinelands National Reserve in southern New Jersey, USA, were used to estimate the effects of defoliation by gypsy moth and prescribed burning on net ecosystem exchange of $\mathrm{CO}_{2}$ (NEE), gross ecosystem production (GEP), evapotranspiration (Et) and ecosystem water use efficiency $\left(W_{U E}\right)$. Pre-disturbance half-hourly NEE at full sunlight conditions (> $1500 \mu \mathrm{mol}$ PPFD m${ }^{-2} \mathrm{~s}^{-1}$ ) and during the nighttime in the summer months, and GEP and $\mathrm{WUE}_{\mathrm{e}}$ during the summer were greater at the oak-dominated stand compared to the mixed and pine-dominated stands. Defoliation by gypsy moth reduced leaf area (LAI) and nitrogen content in foliage, resulting in decreased NEE, GEP and Et at the oak-dominated and mixed stands during the summer months. WUE $_{\mathrm{e}}$ was reduced to 60 and $46 \%$ of pre-disturbance values at the oak-dominated and mixed stands during defoliation, 2 years following complete defoliation at the oak stand, WUE during the summer was $80 \%$ of pre-defoliation values. LAI and foliar $\mathrm{N}$ mass were also reduced by dormant season prescribed burning at the mixed and pine-dominated stands during the next growing season. Midday NEE and daily GEP during the summer months following prescribed burning at the mixed and pine stands averaged 57 and $68 \%$, and 79 and $82 \%$ of pre-disturbance values, respectively. In contrast to gypsy moth defoliation at the oak and mixed stands, prescribed burning at the mixed and pine-dominated stands had no significant effect on $\mathrm{WUE}_{\mathrm{e}}$. Long-term NEE was reduced at the oak-dominated stand, likely due to reduced $\mathrm{N}$ mass in canopy foliage, as well as slightly increased $R_{\text {eco }}$ following mortality of approximately $20 \%$ of mature oak trees. LAI, $\mathrm{N}$ in foliage, NEE, GEP and Et had all recovered to predisturbance levels during the next growing season following the prescribed burn at the pine-dominated stand.

Overall, our results suggest that $\mathrm{WUE}_{\mathrm{e}}$ in forests during and following non-stand-replacing disturbance is dependent on the type of disturbance and the impact on $\mathrm{N}$ status of canopy and understory foliage, in addition to time since disturbance.

Acknowledgements. The authors would like to thank D. Hollinger, P. Stoy, and two anonymous referees for improving earlier versions of this paper.

Edited by: P. Stoy

\section{References}

Allen, S. E. (Ed.): Chemical Analysis of Ecological Materials, Blackwell Scientific Publications, Oxford, 384 pp., 1989.

Allstadt, A. J., Haynes, K. J., Liebhold, A. M., and Johnson, D. M.: Long-term shifts in the cyclicity of outbreaks of a forestdefoliating insect, Oecologia, 172, 141-151, 2013.

Amiro, B. D., Barr, A. G., Barr, J. G., Black, T. A., Bracho, R., Brown, M., Chen, J., Clark, K. L., Davis, K. J., Desai, A. R., Dore, S., Engel, V., Fuentes, J. D., A. H. Goldstein, A. H., Goulden, M. L., Kolb, T. E., Lavigne, M. B., Law, B. E., Margolis, H. A., Martin, T., McCaughey, J. H., Misson, L., Montes-Helu, M., Noormets, A., Randerson, J. T., Starr, G., and Xiao, J.: Ecosystem Carbon Dioxide Fluxes After Disturbance in Forests of North America, J. Geophys. Res., 115, G00K02, 2010. doi:10.1029/2010JG001390, 2010.

Biederman, J. A., Harpold, A. A., Gochis, D. J., Ewers, B. E., Reed, D. E., Papuga, S. A., and Brooks, P. D.: Increased evaporation following widespread tree mortality limits streamflow response, Water Resour. Res., 50, 5395-5409, 2014.

Binford, M. W., Gholz, H. L., Starr, G., and Martin, T. A.: Regional carbon dynamics in the southeastern US coastal plain: Balancing land cover type, timber harvesting, fire, and environmental variation, J. Geophys. Res.-Atmos., 111, D24S92, doi:10.1029/2005JD006820, 2006.

Brümmer, C., Black, T. A., Jassal, R. S., Grant, N. J., Spittlehouse, D. H., Chen, B., Nesic, Z., B. D. Amiro, Altaf Arain, M., Barr, A. G., P.-A. Bourque, C. Coursolle, C., Dunn, A. L., Flanagan, L. B., 
Humphreys, E. R., Lafleur, P. M., Margolis, H. A., McCaughey, J. H., and Wofsy, S. C.: How climate and vegetation type influence evapotranspiration and water use efficiency in Canadian forest, peatland and grassland ecosystems, Agr. Forest Meteorol., 153, 14-30, 2012.

Clark, K. L., Gholz, H. L., Moncrieff, J. B., Cropley, F., and Loescher, H. W.: Environmental controls over net exchanges of carbon dioxide from contrasting Florida ecosystems, Ecol. Appl., 9, 936-948, 1999.

Clark, K. L., Gholz, H. L., and Castro, M. S.: Carbon dynamics along a chronosequence of slash pine plantation in North Florida, Ecol. Appl., 14, 1154-1171, 2004.

Clark, K. L., Skowronski, N., and Hom, J.: Invasive Insects Impact Forest Carbon Dynamics, Glob. Change Biol., 16, 88-101, 2010.

Clark, K. L., Skowronski, N., Gallagher, M., Renninger, H., and Schäfer, K.: Effects of Invasive Insects and Fire on Forest Energy Exchange and Evapotranspiration in the New Jersey Pinelands, Agr. Forest Meteorol., 166-167, 50-61, 2012.

Clark, K. L., Skowronski, N. S., Renninger, H., and Scheller, R.: Climate Change and Fire Management in the mid-Atlantic Region, Forest Ecol. Manag., 327, 306-,315, 2014.

Dore, S., Kolb, T. E., Montes-Helu M., Eckert, S. E., Sullivan, B. W., Hungate, B. A., Kaye, J. P., Hart, S. C., Koch, G. W., and Finkral, A.: Carbon and water fluxes from ponderosa pine forests disturbed by wildfire and thinning, Ecol. Appl., 20, 663-683, 2010.

Dow, C. L.: Assessing regional land-use/cover influences on New Jersey Pinelands streamflow through hydrograph analysis, Hydrol. Process., 21, 185-197, 2007.

Falge, E., Baldocchi, D., Olson, R., Anthoni, P., Aubinet, M., Bernhofer, C., Burba, G., Ceulemans, R., Clement, R., Dolman, H., Granier, A., Gross, P., Grünwald, T., Hollinger, D., Jensen, NO., Katul, G., Keronen, P., Kowalski, A., Lai, C. T., Law, B. E., Meyers, T., Moncrieff, J., Eddy Moors, E., Munger, J. W., Pilegaard, K., Rannik, U., Rebmann, C., Suyker, A., Tenhunen, J., Tu, K., Verma, S., Vesala, T., Wilson, K., and Wofsy, S.: Gap filling strategies for long term energy flux data sets, Agr. Forest Meteorol., 107, 71-77, 2001.

Farquhar, G. D. and Sharkey, T. D.: Stomatal Conductance and Photosynthesis, Ann. Rev. Plant Physio., 33, 317-345, 1982.

Forman, R. T. T. and Boerner, R. E.: Fire frequency and the pine barrens of New Jersey, Bull. Torrey Bot. Club, 108, 34-50, 1981.

Gholz, H. L. and Clark, K. L.: Energy exchange across a chronosequence of slash pine forests in Florida, Agr. Forest Meteorol., 112, 87-102, 2002.

Gholz, H. L., Linder, S., and McMurtrie, R. E.: Environmental constraints on the structure and productivity of pine forest ecosystems: a comparative analysis, Ecol. Bull., 43, 198 pp., 1994.

Gray, D. M. and Dighton, J.: Mineralization of forest litter nutrients by heat and combustion, Soil Biol. Biochem., 38, 1469-1477, 2006.

Gray, D. M. and Dighton, J.: Nutrient utilization by pine seedlings and soil microbes in oligotrophic pine barrens forest soils subjected to prescribed fire treatment, Soil Biol. Biochem., 41, 1957-1965, 2009.

Hicke, J. A., Allen, C. D., Desai, A. R., Dietze, M. C., Hall, R. J., Kashian, D. M., Moore, D., Raffa, K. F., Sturrock, R. N., and Vogelmann, J.: Effects of biotic disturbances on forest carbon cycling in the United States and Canada, Glob. Change Biol., 18, 7-34, 2012.

Hoover, C. M.: Field Measurements for Forest Carbon Monitoring; A Landscape-Scale Approach, Springer Verlag, 242 pp., 2008.

Jassal, R. S., Black, T. A., Spittlehouse, D. L., Brümmer, C., and Nesic, Z.: Evapotranspiration and water use efficiency in different-aged Pacific Northwest Douglas-fir stands, Agr. Forest Meteorol., 149, 1168-1178, 2009.

Kuglitsch, F. G., Reichstein, M., Beer, C., Carrara, A., Ceulemans, R., Granier, A., Janssens, I. A., Koestner, B., Lindroth, A., Loustau, D., Matteucci, G., Montagnani, L., Moors, E. J., Papale, D., Pilegaard, K., Rambal, S., Rebmann, C., Schulze, E. D., Seufert, G., Verbeeck, H., Vesala, T., Aubinet, M., Bernhofer, C., Foken, T., Grünwald, T., Heinesch, B., Kutsch, W., Laurila, T., Longdoz, B., Miglietta, F., Sanz, M. J., and Valentini, R.: Characterisation of ecosystem water-use efficiency of european forests from eddy covariance measurements, Biogeosciences Discuss., 5, 4481-4519, doi:10.5194/bgd-5-4481-2008, 2008.

Lathrop, R. and Kaplan, K. B.: New Jersey land use/land cover update: 2000-2001, New Jersey Department of Environmental Protection, 35 pp., 2004.

Law, B. E., Falge, E., Gu, L., Baldocchi, D., Bakwin, P., Berbigier, P., Davis, K., Dolman, A. J., Falk, M., Fuentes, J. D., Goldstein, A., Granier, A., Grelle, A., Hollinger, D., Janssens, I. A., Jarvis, P., Jensen, N. O., Katul, K., Mahli, Y., Matteucci, G., Meyers, T., Monson, R., Munger, W., Oechel, W., Olson, R., Pilegaard, K., Paw U, K. T., Thorgeirsson, H., Valentini, R., Verma, S., Vesala, T., Wilson, K., and Wofsy, S.: Environmental controls over carbon dioxide and water vapor exchange of terrestrial vegetation, Agr. Forest Meteorol., 113, 97-120, 2002.

Leibhold, A.: Evaluation of forest susceptibility to Gypsy moth across the conterminous United States, available at: http://www. fs.fed.us/ne/morgantown/4557/gmoth/suscept/suscept.html, 2003.

Little, S. and Moore, E. B. The ecological role of prescribed burns in the pine-oak forests of southern New Jersey, Ecology, 30, 223-233, 1949.

Lovett, G. M., Christenson, L. M., Groffman, P. M., Jones, C. G., Hart, J. E., and Mitchell, M. J.: Insect defoliation and nitrogen cycling in forests, BioScience, 52, 335-341, 2002.

Lovett, G. M., Canham, C. D., Arthur, M. A., Weathers, K. C., and Fitzhugh, R. D.: Forest Ecosystem Responses to Exotic Pests and Pathogens in Eastern North America, BioScience, 56, 395-405, 2006.

Matlack, G. R., Gleeson, S. K., and Good, R. E.: Treefall in a Mixed Oak-Pine Coastal Plain Forest: Immediate and Historical Causation, Ecology, 74, 1559-1566, 1993.

Medvigy, D., Clark, K. L., Skowronski, N., and Schäfer, K. V. R.: Simulated impacts of insect defoliation on forest carbon dynamics, Environ. Res. Lett., 7, 045703, doi:10.1088/17489326/7/4/045703, 2012.

McCormick, J. and Jones, L.: The Pine Barrens: Vegetation Geography, Research Report Number 3, New Jersey State Museum, 76 pp., 1973.

Mkhabela, M. S., Amiro, B. D., Barr, A. G., Black, T. A., Hawthorne, I. Kidston, J., McCaughey, J. H., Orchansky, A. L., Nesic, Z., Sass, A. Shashkov, A., and Zha, T.: Comparison of carbon dynamics and water use efficiency following fire and har- 
vesting in Canadian boreal forests, Agr. Forest Meteorol., 149, 783-794, 2009.

Moore, D. J., Trahan, N. A., Wilkes, P., Quaife, T., Stephens, B. B., Elder, K., Desai, A. R., Negron, J., and Monson, R. K.: Persistent reduced ecosystem respiration after insect disturbance in high elevation forests, Ecol. Lett., 16, 731-737, 2013.

Noormets, A., Gavazzi, M. J., McNulty, S. G., Domec, J.-C., Sun, G., King, J. S. and Chen, J.: Response of carbon fluxes to drought in a coastal plain loblolly pine forest, Glob. Change Biol., 16, 272-287, 2010.

Reed, D. E., Ewers, B. E., and Pendall, E.: Impact of mountain pine beetle induced mortality on forest carbon and water fluxes, Environ. Res. Lett., 9, 105004, doi:10.1088/1748-9326/9/10/105004, 2014.

Renninger, H. J., Clark, K. L., Skowronski, N., and Schäfer, K. V. R.: Effects of a prescribed burn on the water use and photosynthetic capacity of pitch pines (Pinus rigida) in the New Jersey Pine Barrens, Trees, 27, 1115-1127, 2013

Renninger, H. J., Carlo, N., Clark, K. L., and Schäfer, K. V. R.: Physiological strategies of co-dominant oaks in a water- and nutrient-limited ecosystem, Tree Physiol., 34, 159-173, 2014a.

Renninger, H. J., Carlo, N., Clark, K. L., and Schäfer, K. V. R.: Modeling respiration from snags and coarse woody debris before and after an invasive insect disturbance, J. Geophys. Res.Biogeo., 119, 630-644, 2014b.

Rhodehamel, E. C.: Hydrology of the New Jersey Pine Barrens, in: Pine Barrens: Ecosystem and Landscape, edited by: Forman, R. T. T., Academic Press, New York, NY, 147-167, 1979.

Schäfer, K. V. R.: Stomatal Conductance Following Drought, Disturbance, and Death in an Upland Oak/Pine Forest of the New Jersey Pine Barrens, USA, Front Plant Sci., 2, 2-15, 2011.

Schäfer, K. V. R., Clark, K. L., Skowronski, N., and Hamerlynck, E. P.: Impact of insect defoliation on forest carbon balance as assessed with a canopy assimilation model, Glob. Change Biol., $16,546-560,2010$.
Schäfer, K. V. R., Renninger, H. J., Clark, K. L., and Medvigy, D.: Hydrological balance in an upland oak/pine forest on the Atlantic Coastal Plain under drought and disturbance, Hydrol. Process., doi:10.1002/hyp.10104, 2013.

Skowronski, N., Clark, K., Nelson, R., Hom, J., and Patterson, M. Remotely sensed measurements of forest structure and fuel loads in the Pinelands of New Jersey, Remote Sens. Environ., 108, 123-129, 2007.

Stoy, P. C., Katul, G. G., Siqueira, M., Juang, J-Y., Novick, K. A., McCarthy, H. R., Oishi, A. C., Uebelherr, J. M., Kim, H-S., and Oren, R. A. M.: Separating the effects of climate and vegetation on evapotranspiration along a successional chronosequence in the southeastern US, Glob. Change Biol. 12, 2115-2135, 2006.

Tedrow, J. C. F.: Soils of New Jersey, New Jersey Agricultural Experiment Station publication A-15134-1-82, Krieger Publishing Co., Malabar, FL, 479 pp., 1986.

Thornton, P. E., Law, B. E., Gholz, H. L., Clark, K. L., Falge, E., Ellsworth, D. S., Goldstein, A. H., Monson, R. K., Hollinger, D. Falk, M., Chen, J., and Sparks, J. P.: Modeling and measuring the effects of disturbance history and climate on carbon and water budgets in evergreen needleaf forests, Agric. Forest Meteorol., 113, 185-222, 2002.

Vickers, D., Thomas, C. K., Pettijohn, C., Martin, J. G., and Law, B. E: Five years of carbon fluxes and inherent water-use efficiency at two semi-arid pine forests with different disturbance histories, Tellus B, 64, 1-14, 2012.

Whittaker, R. H. and Woodwell, G. M.: Dimension and production relations of trees and shrubs in the Brookhaven Forest, New York, J. Ecol., 56, 1-25, 1968. 